ballot paper shall not indicate the method of nomination or the names of those nominating. If the number of nominees does not exceed the number of vacancies, these nominees shall be declared elected at the first meeting, whether of the Council or of the Executive and Finance Committee, after the expiry of the period of four clear weeks in this paragraph referred to.

\title{
Elections to the Fellowship, 1991
}

The Members listed below have been elected as Fellows of the College by the Court of Electors:

Dr M. K. H. Al-Haddad, Dr T. S. Ananthanarayanan, Professor A. M. M. Ashour, Dr M. Atkins, Dr V. F. A. Bailey, Dr A. Y. Beaini, Dr D. S. Bell, Dr S. Bhattacharya, Dr J. M. Bird, Dr J. M. W. Bradford, Dr P. L. Campbell, Dr N. Choudry, Dr P. J. Cowen, Dr F. H. Creed, Dr J. C. Cutting, Professor J. F. W. Deakin, Dr C. M. Dennehy, Dr R. A. H. de Zoysa, Dr T. Dorman, Dr D. P. Eyre, Dr C. J. Farmer, Dr R. C. Fieldsend, Dr M. Fitzgerald, Dr M. P. Greenberg, Dr C. S. O. Hallstrom, Dr L. K. Hanniffy, Dr P. J. Hardwick, Dr B. B. Harris, Dr A. W. Hayman, Dr E. J. Hill, Dr J. E. Hughes, Dr R. K. G. Hughes, Dr D. P. H. Jones, Dr D. R. Knight, Dr R. H. Mahmood, Dr D. R. Master, Dr B. C. McCaffrey, Dr D. C. McInroy, Dr R. B. Milton, Dr G. R. Mir-Sepassi, Dr M. Munro, Dr W. P. J. C. Onyeama, Dr B. M. O'Shea, Dr J. M. Owens, Dr J. M. Penman, Dr S. A. Pidd, Dr I. D. Plant, Dr G. B. Plunkett, Dr M. Ravey, Dr A. M. Reveley, Dr G. J. R. Richardson,
Dr M. F. Robertson, Dr M. M. Robertson, Dr H. P. Rosenvinge, Dr B. K. Saha, Dr A-E-E. A. Salama, Dr G. A. Sampson, Dr M. A. Sheikh, Dr D. H. Skuse, Dr T. A. Spratley, Professor D. J. H. Tantam, Dr N. O. T. Temple, Professor C. Thompson, Dr D. J. Thompson, Dr K. S. Vaddadi, Dr J. P. Wattis, Dr A. C. White, Dr D. G. Wilkinson, Dr D. D. R. Williams, Dr N. M. Yousufzai, Dr S. M. N. Zaidi.

\section{Elections to the Membership under Bye- Law III2ii}

Professor H. S. Akiskal, Dr J. Freedman, Professor R. Garcia, Dr M. Hogan-Murphy, Professor H. I. Maghazaji, Dr M. E. M. Tawfik.

\section{Elections to the New Associate category}

Dr C. J. Gilleard, Professor I. Hindmarch, Dr N. Tarrier.

\section{Locum consultants}

At a recent meeting of College Regional Advisers it was noted that there was a national shortage of suitably qualified psychiatrists able to carry out locum consultant work.

It was agreed that the College would forward to relevant College Regional Advisers the names of those consultant psychiatrists who have recently retired and are willing to undertake this type of work on a short-term basis.
If any retired member is interested in this type of work, could they write to the Secretary enclosing a brief curriculum vitae, together with some indication of the geographical area where they would be willing to work. It would also be helpful to know the length of locums which they would be prepared to fill.

VANESSA CAMERON The Secretary 